\title{
The Correlation between the Levels of Troponin I with the Amount of Leukocytes in Patients Suspected Acute Myocardial Infarction
}

\author{
Tri Prasetyorini* , Rizka Noviyanti, Putu Puja Permata Kasih, Diah Lestari \\ Health Polytechnic of Jakarta III \\ Jakarta, Indonesia \\ *Corresponding author's email: putupuja3 [AT] gmail.com
}

\begin{abstract}
Acute Myocardial Infarction (AMI) is a manifestation of acute myocardial ischemia and is generally caused by the rupture of atherosclerosis and thrombus in the coronary blood vessels. Rupture causes an inflammatory process that leukocytes which acts as a marker of inflammation increases. Heart muscle damage that occurs also resulted in levels of troponin I as one of the markers of increased cardiac examination. Based on that research aims to determine the correlation between the levels of troponin I and the number of leukocytes in patients with suspected AMI.This research method is analytical observation with a data sample of 100 patients with suspected AMI diagnosis by doctors as well as examine the levels of troponin I and the number of leukocytes in dr. Abdulmadjid Chasbullah Bekasi. The correlation between the levels of troponin I and leukocyte counts were analyzed using Spearman's test. Data studied consisted of 52 people (52\%) men and 48 (48\%) of women. By age group, age range 46-65 years become the largest age group into patients with suspected AMI is 55 people (55\%). Obtained 34 (34\%) of patients with suspected AMI who had higher levels of troponin I and normal leukocyte count, and 39 (39\%) of patients with suspected AMI who had troponin I levels and elevated leukocyte count. On Spearman's test seen the correlation between levels of troponin I with the total of leukocytes in patients with suspected AMI $(p=0.000$ and $r=0.50)$. This shows an increase in troponin I, which runs parallel with the increase in the total of leukocytes. Suggested for further research to see the difference increased levels of troponin I and the total of leukocytes between 3-5 hours and 14-18 hours after myocardial injury.
\end{abstract}

Keywords--- Acute Myocardial Infarction (AMI), Troponin I, leukocyte

\section{INTRODUCTION}

Data from the World Health Organization (WHO) in 2012 showed 17.5 million people worldwide died and caused by cardiovascular disease and from all the deaths that caused by cardiovascular disease, 7.4 million were due to coronary heart disease (CHD). The prevalence of CHD in Indonesia itself in the year 2013 under the Basic Health Research estimated at $0.5 \%$ or approximately 883447 inhabitants. The provinces with the highest prevalence of CHD are in Indonesia, West Java province, as many as 160812 people. In 2014, based on a survey of Sample Regristration System (SRS) showed that CHD become the second highest cause of death in all age which is $12.9 \%$ [1].

Coronary Heart Disease (CHD) is a cardiovascular disease in which caused by the heart muscle deficiency of blood supply due to narrowing of coronary arteries. The classic clinical manifestations of CHD is angina pectoris. Angina pectoris is a clinical syndrome which were obtained by chest pain that arise when conducting activities for their myocardial ischemia. Angina pectoris may appear as stable angina pectoris and this situation could develop into a more severe and lead to Acute Coronary Syndrome (ACS), also known as sudden cardiac arrest and could lead to death [2]. . SKA consists of unstable angina pectoris (Unstable Angina Pectis / UAP) and acute myocardial infarction [3].AMI is defined as a term that indicates the area of necrosis due to ischemia [4].AMI is most often caused by atherosclerosis, which can form the thrombus and cause blockages in the coronary arteries [5].

In the diagnosis of the myocardial infarction then do some checks include a physical examination, ECG and laboratory tests [3].. There are times when physical examination and ECG are unclear or doubtful. New ECG abnormalities more evident 12 hours after myocardial infarction arise. Therefore laboratory testing can help supplement the terms of the diagnosis of myocardial infarction, especially in the beginning stages [6]. .

Since 1960 inspection of CK-MB isoenzymes has been accepted as the gold standard for establishing the diagnosis of AMI, it is because the method of CK-MB inspection is easier, faster, and more specific in describing the state of the 
heart muscle compared with total CK, LDH, AST and Myoglobin. But the weakness of CK-MB parameter that is not able to detect a small lesion or old, also a slight increase in other muscle trauma [7].

This time, the biochemical marker troponin I is preferred for the detection of myocardial injury, as almost specific to myocardial tissue, undetectable in the blood of healthy people and showed a high increase above normal values in patients with AMI. Troponin I have a high sensitivity, even can indicate the presence of a small myocardial necrosis. [7]. Troponin I is also considered to better reflect the state of the heart and has a sensitivity and specificity were higher than CK-MB. In addition to cardiac markers examination required other laboratory tests to confirm the diagnosis of AMI including routine blood tests [3].

Leukocyte counts were associated with an area of infarction that occurs because leukocytes plays an important role in the inflammatory response itself, namely the repair mechanisms that aim to replace the area that has been necrosis into collagen $[8,9]$. So that the bigger necrotic area, then the greater will be the response of leukocytes in the systemic and local level [10].

Therefore leukocytes can be used as one of the mediators of inflammation that can be a predictor and prognostic indicator after ischemic events and myocardial infarction [11]. Based on research conducted [12]. reported an increasing number of leukocytes in the majority of patients studied AMI is equal to 57.77\%. Another study conducted [13]. stated that the value of leukocytosis on AMI higher than non AMI patients.

Based on research conducted stated that there is a relationship between the number of leukocytes with troponin I levels in patients with acute myocardial infarction. It is not yet known what levels of troponin I correlation with the number of leukocytes in patients in addition to AMI yet have symptoms such as AMI. Therefore, researchers are interested in knowing the correlation between the levels of troponin I with the number of leukocytes in patients with suspected AMI to know the different correlations in patients with suspected AMI [14].

\section{RESEARCH METHODS}

This research was observational analytic research design with cross sectional approach. The independent variable in this study is the level of troponin I in patients with suspected AMI, while the dependent variable in this study is the number of leukocytes in patients suspected AMI. The data collected is secondary data, laboratory test results of patients with suspected AMI on admission IGD obtained from records or reports recorded in the medical record dr. AbdulmadjidChasbullah Bekasi. The sample used in this study were 100 patients who entered the study because only a sample of 100 patients who met the inclusion criteria that are suspected IMA status data and the results of laboratory tests such as troponin I levels and leukocyte counts were recorded in the patient record status.

\section{RESEARCH RESULT}

Table 1. Frequency Distribution Characteristic of suspected AMI

\begin{tabular}{|c|c|c|c|}
\hline \multicolumn{2}{|c|}{ Variabel } & \multirow{2}{*}{$\begin{array}{c}\begin{array}{c}\text { Frequenci } \\
\text { (n) }\end{array} \\
52\end{array}$} & \multirow{2}{*}{$\begin{array}{c}\begin{array}{c}\text { Present } \\
(\%)\end{array} \\
52 \%\end{array}$} \\
\hline $\operatorname{sex}$ & Male & & \\
\hline & Female & 48 & $48 \%$ \\
\hline Count & & 100 & $100 \%$ \\
\hline \multirow[t]{4}{*}{ Age* } & $12-25$ tahun & 0 & $0 \%$ \\
\hline & $26-45$ tahun & 20 & $20 \%$ \\
\hline & $46-65$ tahun & 55 & $55 \%$ \\
\hline & $\geq 66$ tahun & 25 & $25 \%$ \\
\hline Count & & 100 & $100 \%$ \\
\hline
\end{tabular}

Based on data from medical records of patients with suspected AMI in dr. ChasbullahAbdulmadjid Bekasi City obtained a sample of patients with suspected AMI inspecting troponin I and leukocyte counts as many as 100 patients. there were 52 patients $(52 \%)$ were male and 48 patients $(48 \%)$ of the women, while by age group, there are patients with suspected AMI in the age range of 12-25 years old and the age group of 46-65 years is the age group of patients with suspected AMI most compared with other age groups with the number of 55 patients $(55 \%)$. Retrieved patients with suspected AMI who have 
normal leukocyte counts were 52 patients $(52 \%)$ and patients with suspected AMI who had elevated leukocyte count as many as 48 patients (48\%). As well as patients with suspected AMI not obtained that has a low leukocyte levels.

Table 2. Corellation between Tropinin I with Leukocyte count

\begin{tabular}{llcccc}
\hline \multirow{2}{*}{ Examination } & & \multicolumn{3}{c}{ Total leukocytes } \\
\cline { 3 - 6 } & & \multicolumn{3}{c}{ Normal } & \multicolumn{3}{c}{ High } \\
\cline { 3 - 6 } & & $\mathbf{N}$ & $\mathbf{\%}$ & $\mathbf{N}$ & $\mathbf{9 \%}$ \\
\hline content & Normal & $\mathbf{3 4}$ & $\mathbf{3 4 \%}$ & $\mathbf{9}$ & $\mathbf{3 9 \%}$ \\
\hline
\end{tabular}

Based on the table, obtained the group with higher levels of troponin I and normal leukocyte count as many as 34 patients (34\%). Normal troponin I levels and elevated leukocyte as much as 9 patients (9\%). High levels of troponin I and normal leukocytes of 18 patients $(18 \%)$. The total of respondents with high levels of troponin I and high leukocyte count is 39 patients $(39 \%)$. Based on the results of Spearman correlation test $(\alpha=0.1)$, there is a moderate correlation $(r=0.50)$ and a positive pattern. Statistical test results obtained a correlation between the levels of troponin I with the number of leukocytes in patients with suspected AMI $(\mathrm{p}=0.000)$.

\section{DISCUSSION}

Acute Coronary Syndrome (ACS) is one type of Coronary Heart Disease (CHD). SKA consists of acute myocardial infarction (AMI) and unstable angina pectoris (Unstable angina pectoris / UAP). AMI consists of AMI with an overview of electrocardiography (ECG) ST segment elevation (ST elevation myocardial infarction / STEMI) and AMI without ST segment elevation (non-STEMI). SKA diagnosis can be determined by several criteria, including laboratory procedures such as routine blood tests and cardiac markers [3]. .

From the obtained data normality test levels of troponin I values $<\alpha$ and the value of the number of leukocytes $<\alpha$ that shows both the data are not normally distributed variables, therefore used the Spearman correlation test. Spearman correlation test results show the value of Sig. (2-tailed) $0.000<\alpha(0,1) \mathrm{H} 0$ is rejected, which means that at the $90 \%$ confidence level, there is a moderate positive correlation $(\mathrm{r}=0.50)$ between the levels of troponin $\mathrm{I}$ with the number of leukocytes in patients with suspected AMI. The correlation is consistent with the data contained in Table 4.4 which found the average value of troponin I levels above the normal value that is equal to $1.25 \mathrm{ng} / \mathrm{dl}$ and the average number of leukocytes was also above the normal value that is equal to 10,400 cells $/ \mathrm{mm} 3$. The result of this correlation is also consistent with studies conducted [14].

The alleged correlation because of heart muscle damage that occurs in AMI cause levels of troponin I as a heart muscle specific proteins in the blood increased [6]. . Besides inflammatory processes also occur as a characteristic of the IMA, so the function leuksoit mechanism to improve and phagocytic cells or tissue damaged by inflammation causes leukocyte count increased in the blood circulation $[15,9]$. Inflammation caused by damage to the heart muscle cells can lead to the release of cytokines compound that plays a role in acute inflammation. Under the influence of cytokines, leukocytes from the bone marrow is pulled and moved into the circulation, and will increase the migration of neutrophils from the bone marrow and cause Neutrophilia.

Outcome studies show as many as 39 patients (39\%) of patients with suspected myocardial infarction had troponin I levels and a high leukocyte count. High levels of troponin I that indicate heart muscle damage [16]. While a high leukocyte count indicates an inflammation and inflammation caused by the rupture of atherosclerotic plaques as a cause of IMA. Inflammation also be one [12]. of the triggers formation of atherosclerotic plaque, that is one cause of the occurrence of myocardial infarction which triggers the release of cytokines and chemokines that affect the formation of leukocytes in the body [17]. . Total leukocytes were associated with an area of infarction occurring.

In this study also shows that the research results obtained 34 (34\%) of patients with suspected AMI with high levels of troponin I and normal leukocyte counts. It is possible to patients with suspected AMI experienced unstable angina pectoris (Unstable angina pectoris / UAP) who have symptoms such as IMA but not marked with the ST segment on the ECG and no increase in the results of the markers of heart because unstable angina pectoris is a spectrum of ACS, which is between stable angina pectoris and myocardial infarction are suggesting that in unstable angina pectoris myocardial infarction has not reached [3].

While the research results also showed that there were 18 people $(18 \%)$ of patients with suspected AMI which have high levels of troponin I but with normal leukocytes counts and 9 people (9\%) of patients with suspected AMI with 
normal troponin I levels but had elevated leukocyte count. This might be influenced by a half levels of troponin I, which will be increased in the blood after 3 to 5 hours after injury myocardium, reaching a peak at 14 to 18 hours and remained elevated for 5 to 7 day [7]. Therefore examination of cardiac markers is recommended to be repeated examination 6 to 12 hours after the first examination [6].

Limitations of this study is that the confidence level of $90 \%$ and a large population used to determine the minimum sample is large CHD population in the province of West Java, while the data is only taken at one hospital in Bekasi.

\section{CONCLUSION}

From the results of the study on 100 patients with suspected acute myocardial infarction (AMI) in dr. AbdulmadjidChasbullah Kota Bekasi possible to conclude that moderate correlation $(r=0.50)$ between the levels of troponin I with the number of leukocytes in patients with suspected AMI $(p=0.000)$ at the $90 \%$ confidence level.

\section{REFERENCES}

[1]KementerianKesehatan RI. PenyakitJantungPenyebabKematianTertinggi, KemenkesIngatkan CERDIK. Biro KomunikasidanPelayananMasyarakat,KementerianKesehatan RI. Cited Maret 2017.From :http://www.depkes.go.id/article/view/17073100005/penyakit-jantung-penyebab-kematian-tertinggi-kemenkesingatkan-cerdik-.html, 2017.

[2]Majid, A., PenyakitJantungKoroner, Patofisiologi, Pencegahan, danPengobatanTerkini, JurnalPenelitian, FakultasKedokteranUniversitas Sumatera Utara, Medan, 2007.

[3]PerhimpunanDokterSpesialisKardiovaskuler

Indonesia

(PERKI), PedomanTatalaksanaSindromKoronerAkutEdisiKetiga. Centra Communications, 2015

[4]Kumar V, Abbas AK, Aster JC. BukuAjarPatologi Robbins. Vol. 2. Ed. 9..Elsevier.Singapura.hh. 329-334, 2015.

[5]Aoronson PI, Ward JP. At a glance SistemKardiovaskular. 3rd Edition.Erlangga. Jakarta. p. 94-95, 2008.

[6]Kosasih, E.N., PemeriksaanLaboratoriumKlinik, KARISMA Publishing Group, Tangerang, 2008.

[7]Samsu, N., Sargowo, D., SensitivitasdanSpesifisitas Troponin T dan I pada Diagnosis InfarkMiokardAkut, MajalahKedokteran Indonesia, FakultasKedokteranUnversitasBrawijaya, Malang, 2007.

[8]Grzybowski M, Welch RD, Parsons L, Ndumele CE, Chen E, Zalenski R, et al. The association between WBC and AMI in hospital mortality: findings from the National Registry of Myocardial Infarction. Academic Emergency Medicine.Vol. 11(10).hh: 1049-60, 2004.

[9]Price SA, Wilson LM.. Patofisiologi. In: Pendit BU, Hartanto H, Wulansari P, Mahanani DA, transl. KonsepKlinis Proses-proses Penyakit Vol 1 (6th ed). EGC. Jakarta, 2005.

[10]Núñez JE, Núñez E, Bertomeu V, et al. Prognostic value of baseline white blood cell count in patients with acute myocardial infarction and ST segment elevation.Heart.Vol. 91(8).hh.1094-1095, 2005.

[11]Jee, et al., White Blood Cell Count and Risk for All Cause, Cardiovascular, and Cancer Mortality in a Cohort of Koreans. American Journal of Epidemiology , 2005.

[12]Sitepu, Ade M. Djafar, Dewi U. Panda, Agnes L. GambaranJumlahLeukositpadaPasienInfarkMiokardAkut di RSUP Prof. Dr. R. D. Kandou Manado PeriodeJanuari-Desember 2015.Vol. 4 (2).Jurnal e-Clinic (eCl), 2016.

[13]Maison $\quad$ M.. $\quad$ PerananLeukositosisSebagaiUjiDiagnostikTambahPadaPenderitaInfarkMiokardAkut. UniversitasDiponegoro. Semarang, 2000.

[14]Meidhiyanto, Radiyan. Uddin, Ilham. Sofia, SefriNoventi. HubunganJumlahLeukositTerhadap Kadar Troponin I padaPasienInfarkMiokard. Vol. 5 (4).JurnalKedokteranDiponegoro. 2016. 
[15]Carbone, F. et al., Pathophysiological role of neutrophils in acute myocardial infarction.ThrombHaemost, 2013.

[16]Septiana, A.S.,.KorelasiAktivitas CK-MB dan Kadar Troponin I padaPasienSuspek PJK di RSPAD GatotSoebroto.KaryaTulisIlmiah. JurusanAnalisKesehatan. PoltekkesKemenkes Jakarta III, 2017.

[17]Rafieian-Kopaei, M., Setorki, M., Doudi, M., Baradaran, A., Nasri, H. Atherosclerosis : Process, Indicators, Risk Factors and New Hopes. Vol. 5 (8).International Journal of Preventive Medicine, 2014. 